Review

\title{
Synthesis of the Microbial Polysaccharide Gellan from Dairy and Plant-Based Processing Coproducts
}

\author{
Thomas P. West
}

Citation: West, T.P. Synthesis of the Microbial Polysaccharide Gellan from Dairy and Plant-Based Processing Coproducts. Polysaccharides 2021, 2, 234-244. https://doi.org/10.3390/ polysaccharides 2020016

Academic Editor: Sabina Górska

Received: 13 February 2021

Accepted: 29 March 2021

Published: 6 April 2021

Publisher's Note: MDPI stays neutral with regard to jurisdictional claims in published maps and institutional affiliations.

Copyright: (C) 2021 by the author. Licensee MDPI, Basel, Switzerland. This article is an open access article distributed under the terms and conditions of the Creative Commons Attribution (CC BY) license (https:// creativecommons.org/licenses/by/ $4.0 /)$.
Department of Chemistry, Texas A\&M University-Commerce, Commerce, TX 75429, USA; Thomas.West@tamuc.edu; Tel.: +1-903-886-5399

\begin{abstract}
This review examines the production of the microbial polysaccharide gellan, synthesized by Sphingomonas elodea, on dairy and plant-based processing coproducts. Gellan is a water-soluble gum that structurally exists as a tetrasaccharide comprised of $20 \%$ glucuronic acid, $60 \%$ glucose and $20 \%$ rhamnose, for which various food, non-food and biomedical applications have been reported. A number of carbon and nitrogen sources have been tested to determine whether they can support bacterial gellan production, with several studies attempting to optimize gellan production by varying the culture conditions. The genetics of the biosynthesis of gellan has been explored in a number of investigations and specific genes have been identified that encode the enzymes responsible for the synthesis of this polysaccharide. Genetic mutants exhibiting overproduction of gellan have also been identified and characterized. Several dairy and plant-based processing coproducts have been screened to learn whether they can support the production of gellan in an attempt to lower the cost of synthesizing the microbial polysaccharide. Of the processing coproducts explored, soluble starch as a carbon source supported the highest gellan production by $S$. elodea grown at $30{ }^{\circ} \mathrm{C}$. The corn processing coproducts corn steep liquor or condensed distillers solubles appear to be effective nitrogen sources for gellan production. It was concluded that further research on producing gellan using a combination of processing coproducts could be an effective solution in lowering its overall production costs.
\end{abstract}

Keywords: gellan; polysaccharide; applications; culture conditions; genetics; mutants; processing coproducts; Sphingomonas elodea

\section{Introduction}

The purpose of this review is to provide both background about the microbial polysaccharide gellan and, more specifically, to examine bacterial gellan synthesis on dairy and plant-based processing coproducts. The anionic heteropolysaccharide gellan is known to be synthesized by Sphingomonas elodea strain ATCC 31461 [1,2]. Although originally classified as Pseudomonas elodea, this strain was reclassified as a species of Sphingomonas [3,4]. Structurally, the water-soluble gum gellan exists as a tetrasaccharide composed of $20 \%$ glucuronic acid, $60 \%$ glucose and $20 \%$ rhamnose [5-7]. The native form of gellan has been shown to contain acetyl and L-glyceryl groups. These substituents need to be removed by an alkaline heat treatment to produce a gel. The degree of deacetylation of gellan can be directly correlated to its gel-forming ability [8]. The alkaline treatment of the native biopolymer results in a tetrasaccharide sequence that is anionic (Figure 1). As the deacylated biopolymer cools, a double helix forms from the disordered coils which results in gelation. Gelation of the polysaccharide is enhanced when the $\mathrm{pH}$ of the polysaccharide becomes more acidic. An acidic $\mathrm{pH}$ diminishes the negative charge of the polysaccharide molecule that results in greater repulsion within the helix. The addition of monovalent cations to a gellan solution increases its rate of gelation [9-14]. 


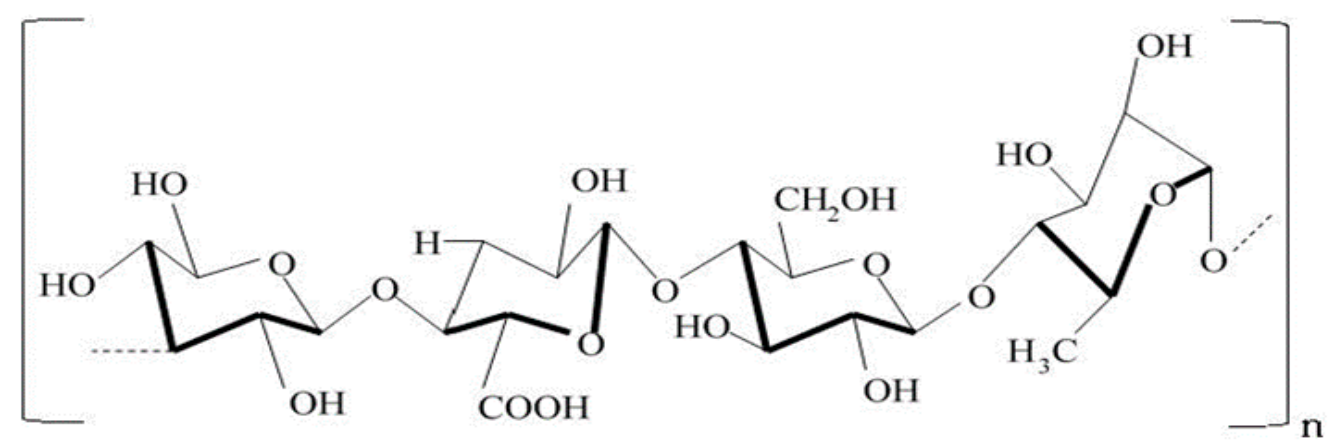

Figure 1. The structure of gellan involves tetrasaccharide repeating units consisting of two molecules of D-glucose as well as one molecule each of L-rhamnose and D-glucuronic acid.

When the monovalent cations bind to the helices, they bind to interact with the carboxylate groups on the polysaccharide to diminish repulsion within the helices. The binding of the monovalent ions to the helices increases with ionic size. Gellan behaves like a normal polymer solution when low monovalent cation concentrations are present. As the monovalent cation concentration is increased, a self-supporting gel is formed. The addition of divalent cations to a gellan solution also increases its rate of gelation [9-17]. The divalent cations bind between the helices to cause gelation. High concentrations of divalent cations results in a reduction in gel strength. It has been shown that the concentration of divalent cations needs to be equivalent to the carboxylate group content of the gellan to achieve maximum gellan strength. It has been noted that to achieve maximum gel strength, a higher concentration of monovalent cations needs to be added to the polymer solution than the divalent cation concentration. The binding properties of gellan allowed a colorimetric assay to be developed using the dye toluidine blue $\mathrm{O}$ where the gellan assay was found to be linear up to a concentration of $0.7 \mathrm{~g} / \mathrm{L}$ [18].

In the United States, the source of commercial gellan production is C.P. Kelco (Atlanta, GA, USA). There are a number of commercial applications reported for this polysaccharide gum. With respect to food applications, gellan is used in confectionery jellies, fabricated foods, pie fillings and puddings, bakery icings and frostings, dairy products, fruit, milkbased and carbonated beverages as well as film or coatings for food adhesion [19-23]. With respect to non-food applications, gellan was originally proposed as a replacement for agar in microbial growth media since agar is the most economical polysaccharide gum available to be used as a solidifying agent that produces opaque gels [24-26]. Gellan has found greater use as a substitute for agar in plant tissue culture. The higher clarity of the gels at lower gellan concentrations is a marked advantage over agar. Another advantage of gellan is that it contains less impurities compared to agar. The use of gellan gels in plant tissue cultures allows tissue development to be observed more clearly than using agar. Gellan also has a number of pharmaceutical uses for drug delivery and enzyme immobilization [27-34]. With its non-toxicity, rapid gelation, ability to retain water and its biodegradability, gellan is used in oral formulations for drug delivery in capsules, beads and tablets. In opthamalic formulations, it is used in in situ gelling solutions to deliver antiglaucoma and anti-conjunctivitis drugs [35]. Gellan is employed in nasal formulations as an in situ nasal gel to deliver a variety of pharmaceuticals. Another biomedical application of gellan is its use in wound healing where its properties have promise to serve as a carrier in tissue engineering [36-40].

\section{Effect of Culture Conditions on Gellan Production by Sphingomonas elodea \\ 2.1. Effect of Carbon Source}

Relative to the carbon source, glucose-grown cells of S. paucimobilis strain ATCC 31461 were first shown to synthesize gellan $[1,14]$. A model developed to optimize gellan production was devised using ATCC 31461 in a simplified 3\% glucose-containing medium [41]. It has been shown that maximum yield and productivity for ATCC 31461 were determined 
in a medium containing $1 \%$ glucose when no nitrogen source was present [42]. The strain ATCC 31461 was also shown to synthesize gellan on sucrose, mannose, galactose, fructose or maltose as a carbon source after $72 \mathrm{~h}$ of growth at $30{ }^{\circ} \mathrm{C}$ [43]. It was also found that cellular biomass production by ATCC 31461 did not correlate with gellan synthesis [43]. A prior study examining the effect of carbon source concentration of glucose and sucrose noted that polysaccharide production was maximal after $52 \mathrm{~h}$ in a $\mathrm{pH}$ 7.0-buffered medium containing $3 \%$ glucose or $4 \%$ sucrose at $30{ }^{\circ} \mathrm{C}$ [44]. With respect to the optimal incubation temperature for ATCC 31461 cells grown in a glucose-containing medium, it was shown to be $30-31{ }^{\circ} \mathrm{C}$ [45]. Similarly, cellular productivity was maximum for gellan production at $31{ }^{\circ} \mathrm{C}$ after $72 \mathrm{~h}$ of growth in batch cultures [45]. A two-stage culture strategy was developed to improve gellan production by ATCC 31461 using sucrose as a carbon source. This strategy was based on the findings that lower sucrose concentrations and higher temperatures favored bacterial cell growth but not gellan synthesis while low cell growth was observed when higher sucrose concentrations and lower temperatures were used which favored increased gellan production. The initial stage of the process involved pulse fed batch feeding of the culture during the first $24 \mathrm{~h}$. ATCC 31461 cells were cultured in a pulse fed-batch mode with an initial sucrose concentration $10 \mathrm{~g} / \mathrm{L}$ at $33^{\circ} \mathrm{C}$ while the second stage involved incubating the batch culture at $28{ }^{\circ} \mathrm{C}$ to promote gellan production [46]. The influence of the initial $\mathrm{pH}$ of a glucose-containing culture medium on gellan synthesis by ATCC 31461 was analyzed. When the initial $\mathrm{pH}$ of the culture medium was 6.8 to 7.4 , it was observed that gellan formation was greatest after $72 \mathrm{~h}$ of growth at $30^{\circ} \mathrm{C}$. Biomass production by the ATCC 31461 after $72 \mathrm{~h}$ was highest when the initial $\mathrm{pH}$ of the glucose-containing medium was adjusted to 7.8 [47]. Lastly, the effect of adding the glucose analog 2-deoxy-D-glucose to ATCC 31461 cultures was examined. When $50 \mu \mathrm{g} / \mathrm{L} 2$-deoxyD-glucose was added to the ATCC 31461 culture medium after $24 \mathrm{~h}$, it was observed that the highest gellan concentration $(20.78 \mathrm{~g} / \mathrm{L})$ was produced. The activity of UDP-glucose pyrophosphorylase activity was inhibited while the glucosyltransferase activity was elevated. It was thought that the glucose analog greatly inhibited glycolysis while activating the biosynthetic pathway for gellan in ATCC 31461 cells [48].

\subsection{Influence of Nitrogen Source}

The effect of a complex nitrogen source substituting for ammonium nitrate in a glucosecontaining culture medium of ATCC 31461 was explored [43]. The complex nitrogen source tested was soytone (hydrolyzed soy protein), corn steep liquor, corn steep solids, ethanol stillage, peptone or tryptone [43]. In all cases, the complex nitrogen source promoted higher gellan production by ATCC 31461 in the glucose-containing medium compared to the medium containing glucose as the carbon source and ammonium nitrate as the nitrogen source [43]. Gellan production by ATCC 31461 was found to be highest in a medium containing glucose and soytone. It was also observed that soytone stimulated ATCC 31461 biomass production in the glucose-containing medium [43]. Having determined that the nitrogen source soytone enhanced gellan production by ATCC 31461, yeast extract supplementation of the glucose-containing medium was studied to learn whether the yeast extract concentration in the medium could further promote gellan production [49]. It was determined that only if the concentration of yeast extract in the glucose-containing medium was $0.1 \%$ did the polysaccharide level produced by ATCC 31461 increase significantly.

\subsection{Effect of Aeration and Surfactants}

The effect of aeration on gellan and cell biomass biosynthesis by ATCC 31461 was investigated. Biomass production was higher than gellan production by the bacterium as aeration and dissolved oxygen tension was elevated [50]. It was observed that $100 \%$ dissolved oxygen tension caused the gellan yield to increase to $23 \mathrm{~g} / \mathrm{L}$, with the polysaccharide being synthesized having increased viscosity and molecular weight. Another study found that high dissolved oxygen tension was not required for elevated gellan synthesis. Instead, it appeared that maximum gellan synthesis by the sphingomonad occurred when 
oxygen limitation preceded the initiation of gellan formation. It was also concluded that maximum gellan production by the bacterium did not correlate with maximum cellular biomass production [51]. It has been reported that treatment with $2-4 \mathrm{mM}$ hydrogen peroxide of sphingomonad cells over a period of $12 \mathrm{~h}$ resulted in $36 \%$ greater gellan production than the untreated cells. In addition, cell growth was noted to be inhibited by the presence of hydrogen peroxide. The study found that oxidative stress placed upon the bacterial cells resulted in the enzymes UDP-glucose pyrophosphorylase activity and glucosyltransferase activity being elevated [52]. The increase in these enzyme activities likely accounts for the enhanced bacterial gellan production. The addition of the non-ionic surfactants Tween 80, Tween 40 and Triton X-100 to the medium of ATCC 31461 cultures were studied to determine whether they affected gellan synthesis [53]. It was observed that supplementation of each surfactant enhanced polysaccharide production by ATCC 31461 cells. A 1.2-fold increase in gellan synthesis by ATCC 31461 was noted when $0.75 \mathrm{~g} / \mathrm{L}$ Triton X-100 was present in the culture medium compared to gellan production by ATCC 31461 cells grown in unsupplemented culture medium. Surfactant supplementation of the bacterial cultures also resulted in a high viscosity polysaccharide being synthesized. The same study found that the gellan yield $(14.62 \mathrm{~g} / \mathrm{L})$ was highest in a $5 \mathrm{~L}$ laboratory fermentor incubated at $29.6^{\circ} \mathrm{C}$ in a culture medium buffered at $\mathrm{pH} 6$ containing $1.0 \mathrm{~g} / \mathrm{L}$ Triton X-100 [53]. Gellan production by ATCC 31461 in the fermentor could be elevated by 1.9-fold with an aeration speed of $1000 \mathrm{rpm}$ and a 100\% dissolved oxygen tension similar to what was observed in an earlier study $[50,53]$.

\section{Genetics of Gellan Biosynthesis and Mutant Isolation}

\subsection{Genetics of Gellan Biosynthesis}

A number of investigations have explored the pathways thought to be involved in the synthesis of gellan. The enzymes thought to be involved in the pathway of gellan synthesis include phosphoglucomutase, dTDP-D-glucose pyrophosphorylase, dTDP-D-glucose 4,6dehydratase, dTDP-4-dehydrorhamnose 3,5 epimerase, dTDP-4-dehydrorhamnose reductase, glucose-1-phosphate uridyltransferase and UDP-D-glucose dehydrogenase (Figure 2). It has been shown that S. elodea ATCC 31461 contains a gene cluster of 18 genes. The identified genes showed a high degree of homology to the genes responsible for sphingan synthesis in Sphingomonas sp. ATCC 31554 [54]. Interestingly, the genes encoding the glycosyl transferases showed little homology. The $r m l$ gene cluster, consisting of four genes, is thought to be involved in the synthesis of dTDP-rhamnose [55]. The first gene of the gene cluster is $r m l A$ which was shown to encode an enzyme that exhibited dTDP-glucose pyrophosphorylase following expression of the gene in Escherichia coli. Characterization of the bacterial fusion protein of the pyrophosphorylase revealed that it had a $\mathrm{K}_{\mathrm{m}}$ of $12.0 \mu \mathrm{M}$ for dTDP-glucose. It is known that pgmG encodes phosphoglucomutase [55]. Another study performed protoplast fusion experiments with S. elodea ATCC 31461 and the genes, rmlA and $p g m G$ were cloned [56]. The approximate molecular weight of the $r m l A$ protein was $50 \mathrm{kDa}$ while the molecular weight of the $p g m G$ protein was $31 \mathrm{kDa}$. The enzyme glucose-1phosphate uridylyltransferase, encoded by $u g p G$, catalyzes the production of UDP-glucose and pyrophosphate from its substrates glucose-1-phosphate and UTP in S. elodea ATCC 31461 [57]. The X-ray crystal structure of the glucose-1-phosphate uridylyltransferase from ATCC 31461 has been elucidated [58]. It was reported that there is monomeric structural similarity between glucose-1-phosphate uridylyltransferase and glucose-1-phosphate thymidylyltransferase. In S. elodea ATCC 31461, the enzyme UDP-glucose dehydrogenase was shown to be encoded by $u g d G$ gene since the dehydrogenase was synthesized when the gene was expressed recombinantly in E. coli [59]. The dehydrogenase produces UDP-Dglucuronic acid from UDP-D-glucose. The $\mathrm{K}_{\mathrm{m}}$ values of the recombinant dehydrogenase for its substrate UDP-glucose or $\mathrm{NAD}^{+}$was 0.87 or $0.4 \mathrm{mM}$, respectively. The temperature optimum for the dehydrogenase was $37^{\circ} \mathrm{C}$ while its $\mathrm{pH}$ optimum was 8.7. A regulatory gene affecting gellan synthesis by ATCC 31461 was also thought to have been identified [54]. The concentration and viscosity of gellan was noted to be affected by the products of the 
three genes gell, gelM and gelN [54]. With respect to the metabolism of glucose by the bacterium to synthesize gellan, the production of glucose-6-phosphate and gluconate are necessary so that they can be utilized by the Entner-Doudoroff and pentose phosphate pathways plus the enzyme glucose-6-phosphate dehydrogenase was also thought to be involved in gellan synthesis [60].

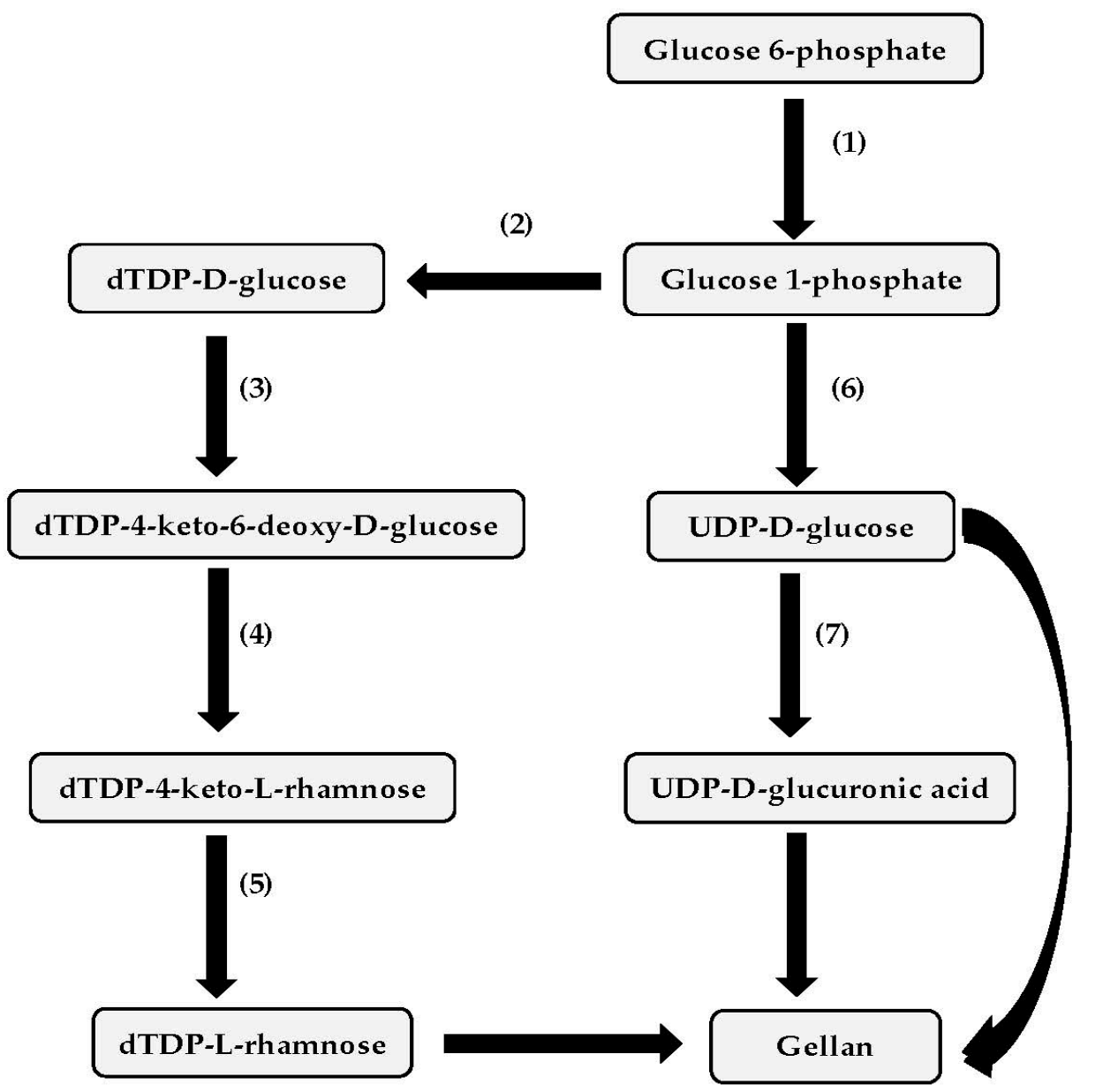

Figure 2. The metabolic pathways in Sphingomonas elodea thought to be involved in gellan synthesis [54-59]. The pathway enzymes involved include (1) phosphoglucomutase; (2) dTDP-D-glucose pyrophosphorylase; (3) dTDP-D-glucose 4,6-dehydratase; (4) dTDP-4-dehydrorhamnose 3,5 epimerase; (5) dTDP-4-dehydrorhamnose reductase; (6) glucose-1-phosphate uridyltransferase; (7) UDP-Dglucose dehydrogenase. Abbreviations: UDP, uridine diphosphate; dTDP, thymidine diphosphate.

\subsection{Mutant Isolation Related to Gellan Production}

A mutant strain of the S. elodea ATCC 31461 was isolated using chemical mutagenesis and resistance to the antibiotic ampicillin [61,62]. Using glucose or corn syrup as a carbon source, the isolated mutant demonstrated enhanced gellan production [61]. Compared to its parent strain ATCC 31461, the mutant strain produced approximately double the gellan concentration on glucose or corn syrup after $48 \mathrm{~h}$ of growth at $30^{\circ} \mathrm{C}$, and decreased to approximately 1.4-fold higher after $72 \mathrm{~h}$ of growth at $30^{\circ} \mathrm{C}$. It was noted that there was no correlation between biomass production and gellan production by the mutant strain. A correlation between increased gellan production by the mutant strain on either carbon source and an increase in culture medium viscosity was observed. There was no difference in the glucuronic acid content of the gellan produced by the mutant and parent strains [61]. A problem with ATCC 31461 is that it accumulates yellow carotenoid pigments and poly- $\beta$-hydroxybutyrate which results in diminished levels of gellan [63]. Pigment removal from the polysaccharide also increases processing costs in gellan production. A 
possible solution to this problem was to engineer a mutant strain that did not accumulate pigment and poly- $\beta$-hydroxybutyrate. A mutant strain was isolated where carotenoid and poly- $\beta$-hydroxybutyrate syntheses were blocked but its ability to synthesize gellan was diminished [63]. Using this double mutant strain, a further effort was employed to isolate a strain exhibiting increased gellan production. The resultant strain isolated produced approximately a 1.4-fold higher gellan concentration than ATCC 31461 after $48 \mathrm{~h}$ of growth at $30{ }^{\circ} \mathrm{C}$ in a sucrose-containing medium.

\section{Gellan Synthesis on Processing Coproducts}

\subsection{Dairy Processing Coproduct}

A number of crop processing coproducts have been tested in an effort to lower the overall cost of producing the polysaccharide gellan commercially (Table 1). One such coproduct is whey from dairy processing. A surplus of the lactose-rich whey exists and studies have examined whether whey could be utilized as a carbon source for gellan production $[64,65]$. One study found that whey containing $4.9 \%$ lactose was able to sustain gellan production by ATCC 31461 when tryptone served as the nitrogen source. Dilution of the whey by 1:4 resulted in the highest level of gellan production by ATCC 31461 [64]. Another investigation examining whey as a carbon source and peptone as a nitrogen source also found that dilution of the whey by 1:4 resulted in the highest level of gellan being produced by ATCC 31461 [65].

\subsection{Corn Processing Coproducts}

Maltose corn syrup is a processing coproduct that is synthesized from the wet milling of corn. The conversion of corn starch into corn syrup occurs using a dual acid enzyme conversion process where the level of maltose is about $42 \%$. In a number of studies (Table 1 ), the maltose corn syrup was used as a carbon source while various nitrogen sources were screened to learn which combination allowed the highest gellan production by ATCC $31461[43,45,47,48,61,66,67]$. It was observed that in a corn syrup-containing medium that using corn steep liquor as a nitrogen source resulted in a higher level of gellan production by ATCC 31461 than when ATCC 31461 utilized soytone, corn steep solids, tryptone or peptone as a nitrogen source [43]. Similarly, an investigation where a glucose-containing medium in which corn steep liquor served as a nitrogen source caused a high level of gellan to be produced by strain ZJUT 1008 [68]. The advantage of using corn steep liquor as a nitrogen source in the medium is that it is more cost effective than using yeast extract or ammonium salts as a nitrogen source. Another processing coproduct is condensed corn solubles which is derived from the dry milling of corn for ethanol production [69]. One advantage of using condensed corn solubles is that the solubles contains components found in yeast extract and ammonium salts. It was determined that when the solubles was included in a $3 \%$ glucose-containing medium ( $\mathrm{pH}$ 6.5) in a bioreactor incubated at $28{ }^{\circ} \mathrm{C}$, gellan production by ATCC 31461 was shown to be higher on condensed corn solubles than the standard medium containing yeast extract and ammonium salts. It was concluded that condensed corn solubles as a gellan production medium substitute could substantially reduce the commercial production cost of gellan [69]. 
Table 1. Gellan production by strains grown on processing coproducts.

\begin{tabular}{|c|c|c|c|c|c|}
\hline Sphingomonas elodea Strain & Carbon Source & Nitrogen Source & Growth Conditions & Gellan (G/L) & Reference \\
\hline ATCC 31461 & Maltose corn syrup & Corn steep solids & $72 \mathrm{~h}, 30^{\circ} \mathrm{C}$ & 2.71 & [43] \\
\hline ATCC 31461 & Maltose corn syrup & Corn steep solids & $72 \mathrm{~h}, 30^{\circ} \mathrm{C}$ & 2.98 & [43] \\
\hline ATCC 31461 & Maltose corn syrup & Tryptone & $72 \mathrm{~h}, 30^{\circ} \mathrm{C}$ & 1.93 & [43] \\
\hline ATCC 31461 & Maltose corn syrup & Peptone & $72 \mathrm{~h}, 30^{\circ} \mathrm{C}$ & 1.80 & [43] \\
\hline ATCC 31461 & Soluble starch & Peptone & $72 \mathrm{~h}, 30^{\circ} \mathrm{C}$ & 5.73 & [44] \\
\hline ATCC 31461 & Maltose corn syrup & $\begin{array}{l}\text { Hydrolyzed soy } \\
\text { protein }\end{array}$ & $72 \mathrm{~h}, 30^{\circ} \mathrm{C}$ & 2.24 & [60] \\
\hline EGP-1 & Maltose corn syrup & $\begin{array}{c}\text { Hydrolyzed soy } \\
\text { protein }\end{array}$ & $72 \mathrm{~h}, 30^{\circ} \mathrm{C}$ & 3.20 & [60] \\
\hline ATCC 31461 & Whey & Tryptone & $64 \mathrm{~h}, 28^{\circ} \mathrm{C}$ & 3.10 & [64] \\
\hline ATCC 31461 & Whey & Peptone & $72 \mathrm{~h}, 30^{\circ} \mathrm{C}$ & 7.90 & [65] \\
\hline ZJUT 1008 & Glucose & Corn Steep liquor & $72 \mathrm{~h}, 30^{\circ} \mathrm{C}$ & 14.41 & [68] \\
\hline ATCC 31461 & Glucose & $\begin{array}{c}\text { Condensed corn } \\
\text { solubles }\end{array}$ & $82 \mathrm{~h}, 30^{\circ} \mathrm{C}$ & 13.40 & [69] \\
\hline ATCC 31461 & Soluble starch & Tryptone & $48 \mathrm{~h}, 30^{\circ} \mathrm{C}$ & 24.32 & [70] \\
\hline ATCC 31461 & Soluble starch & $\begin{array}{c}\text { Yeast ex- } \\
\text { tract/tryptophan }\end{array}$ & $48 \mathrm{~h}, 30^{\circ} \mathrm{C}$ & 43.60 & [71] \\
\hline ATCC 31461 & Molasses & Tryptone & $48 \mathrm{~h}, 30^{\circ} \mathrm{C}$ & 13.81 & [72] \\
\hline NK 2000 & Glucose & Soybean pomace & $72 \mathrm{~h}, 30^{\circ} \mathrm{C}$ & 7.50 & [73] \\
\hline ATCC 31461 & $\begin{array}{c}\text { Olive oil waste } \\
\text { water }\end{array}$ & Yeast extract & $63 \mathrm{~h}, 30^{\circ} \mathrm{C}$ & 6.80 & [74] \\
\hline
\end{tabular}

\subsection{Soluble Starch as a Carbon Source for Gellan Production}

Selected concentrations of soluble starch have been tested as a possible carbon source (Table 1) to support gellan production by ATCC $31461[44,70,71]$. When $2 \%$ soluble starch was included in a medium containing peptone as a nitrogen source, it was observed that ATCC 31461 produced $5.73 \mathrm{~g} / \mathrm{L}$ gellan after $72 \mathrm{~h}$ at $30^{\circ} \mathrm{C}$ [44]. Another study also used $2 \%$ soluble starch as a carbon source for gellan production by ATCC 31461 but tryptone was utilized as the nitrogen source in the culture medium [70]. It was reported that $4 \%$ soluble starch supported a higher level of gellan $(44.2 \mathrm{~g} / \mathrm{L})$ by ATCC 31461 than if the strain was grown on $2 \%$ soluble starch [70]. It was not clear if the higher gellan concentration produced by ATCC 31461 was due to unused soluble starch also being precipitated in addition to the gellan. A third study also used soluble starch as a carbon source for the production of gellan by ATCC 31461 [71]. A statistical approach was taken to determine the optimum conditions for gellan production by ATCC 31461 on $4 \%$ soluble starch. It was determined that a concentration of $43.6 \mathrm{~g} / \mathrm{L}$ of starch-free gellan was synthesized by ATCC 31461 in the presence of yeast extract, tryptophan and ADP in the culture medium after $48 \mathrm{~h}$ at $30^{\circ} \mathrm{C}$. This gellan concentration is a substantially higher than previously reported levels of gellan produced by ATCC 31461 on processing coproducts [71]. It appeared that soluble starch could be an ideal substrate for bacterial gellan production.

\subsection{Other Processing Coproducts}

Another processing coproduct examined as a substrate for bacterial gellan mutant was molasses from cane processing (Table 1). A fermentor containing $3 \mathrm{~L}$ of culture medium containing $1.125 \%$ molasses as a carbon source and tryptone as a nitrogen source supported the production of $13.81 \mathrm{~g} / \mathrm{L}$ gellan by ATCC 31461 after $48 \mathrm{~h}$ at $30^{\circ} \mathrm{C}$ [72]. In a glucose-containing medium (Table 1), gellan production by a S. elodea strain NK2000 was investigated to determine whether soybean pomace was an effective nitrogen source [73]. 
Soybean pomace is a processing coproduct of the soy sauce industry. It was found that strain NK2000 produced a higher gellan concentration on soybean pomace than peptone in a bioreactor after $72 \mathrm{~h}$ at $30^{\circ} \mathrm{C}$. This indicated that soybean pomace could substitute for peptone in a gellan production medium which make the production of the polysaccharide more economical [73]. A processing coproduct of olive oil production is olive mill waste water. When olive mill waste water was utilized as a carbon source and yeast extract was used as a nitrogen source in the culture medium (Table 1), ATCC 31461 was shown to synthesize gellan in a fermentor [74]. After $63 \mathrm{~h}$ at $30^{\circ} \mathrm{C}$, ATCC 31461 produced $6.8 \mathrm{~g} / \mathrm{L}$ gellan in a $15 \mathrm{~L}$ stirred tank bioreactor with a $10 \mathrm{~L}$ working volume. The addition of glycerol to the medium caused a slight increase in gellan production by ATCC 31461 after $63 \mathrm{~h}$ in the bioreactor [74].

From comparing the possible lower cost processing coproducts that could be utilized to commercially synthesize gellan, it appeared from the earlier studies that soluble starch as a carbon source was capable of supporting the highest level of gellan by ATCC 31461. Considering that the concentration of nitrogen source added to the medium is much lower than the carbon source concentration, soluble starch probably could have a greater impact on lowering the production cost of gellan. A production medium for gellan synthesis where soluble starch is used as the carbon source and another cheaper processing coproduct, such as corn steep liquor or condensed corn solubles, serves as the nitrogen source could be developed so that large-scale gellan production could become more economical. This may lead to a decrease in the cost of gellan which would make it competitive to the production costs of other commercially available polysaccharides.

\section{Conclusions}

In summary, there appears to be an opportunity to use low-value processing coproducts to synthesize the commercially available polysaccharide gellan. From an economic perspective, development of a coproduct-based process to synthesize gellan at a lower price could increase its large-scale production and likely increase the number of industrial applications for gellan. With many of the processing coproducts considered as waste products that often pollute the environment, their use in large-scale polysaccharide production would greatly reduce any impact that they have on the environment. It can be concluded that further research is necessary to identify the appropriate combination of processing coproducts for optimal microbial production of gellan.

Funding: This research was funded by the Welch Foundation Grant T-0014 and the South Dakota Agricultural Experiment Station Grant No. SD00067-H.

Institutional Review Board Statement: Not applicable.

Informed Consent Statement: Not applicable.

Data Availability Statement: Not applicable.

Conflicts of Interest: The author declares no conflict of interest.

\section{References}

1. Kang, K.S.; Veeder, G.T.; Mirrasoul, P.J.; Kaneko, T.; Cottrell, I.W. Agar-like polysaccharide produced by a Pseudomonas species: Production and basic properties. Appl. Environ. Microbiol. 1982, 43, 1086-1091. [CrossRef]

2. Anson, A.; Fisher, P.J.; Kennedy, A.F.D.; Sutherland, I.W. A bacterium yielding a polysaccharide with unusual properties. J. Appl. Bacteriol. 1987, 62, 147-150. [CrossRef]

3. Pollock, T.J. Gellan-related polysaccharides and the genus Sphingomonas. J. Gen. Microbiol. 1993, 139, 1939-1945. [CrossRef]

4. West, T.P. Pyrimidine nucleoside catabolism in Sphingomonas paucimobilis: Role of cytidine deaminase and uridine phosphorylase. Microbiol. Res. 1995, 150, 149-152. [CrossRef]

5. O'Neil, M.A.; Silvendran, R.R.; Morris, J. Structure of extracellular gelling polysaccharide produced by Pseudomonas elodea. Carbohydr. Res. 1983, 124, 123-133. [CrossRef]

6. Jansson, P.-E.; Lindberg, B.; Sandford, P.A. Structural studies of gellan gum, an extracellular polysaccharide elaborated by Pseudomonas elodea. Carbohydr. Res. 1983, 124, 135-139. [CrossRef] 
7. Chandrasekaran, R.; Millane, R.P.; Arnott, S.; Atkins, E.D.T. The crystal structure of gellan. Carbohydr. Res. 1988, 175, 1-15. [CrossRef]

8. Campana, S.; Ganter, J.; Milas, M.; Rinaudo, M. On the solution properties of bacterial polysaccharides of the gellan family. Carbohydr. Res. 1992, 231, 31-38. [CrossRef]

9. Crescenzi, V.; Dentini, M.; Dea, I.C.M. The influence of side-chains on the dilute-solution properties of three structurally related bacterial anionic polysaccharides. Carbohydr. Res. 1987, 160, 283-302. [CrossRef]

10. Chandrasekaran, R.; Puigjaner, L.C.; Joyce, K.L.; Arnott, S. Cation interactions in gellan: An X-ray study of the potassium salt. Carbohydr. Res. 1988, 181, 23-40. [CrossRef]

11. Chandrasekaran, R.; Radha, A.; Thailambal, V.G. Roles of potassium ions, acetyl and L-glyceryl groups in native gellan double helix: An X-ray study. Carbohydr. Res. 1992, 224, 1-17. [CrossRef]

12. Tang, J.; Lelievre, J.; Tung, M.A.; Zeng, Y. Polymer and ion concentration effects on gellan strength and strain. J. Food Sci. 1994, 59, 216-220. [CrossRef]

13. Tang, J.; Tung, M.A.; Zeng, Y. Mechanical properties of gellan gels in relation to divalent cations. J. Food Sci. 1995, 60, 748-752. [CrossRef]

14. Manna, B.; Gambhir, A.; Ghosh, P. Production and reheological characteristics of the microbial gum gellan. Lett. Appl. Microbiol. 1996, 23, 141-145. [CrossRef]

15. Kirchmajer, D.M.; Steinhoff, B.; Warren, H.; Clark, R.; in het Panhuis, M. Enhanced gelation properties of purified gellan gum. Carbohydr. Res. 2014, 388, 125-129. [CrossRef]

16. Sharma, S.; Bhattacharya, S. Flow behaviour of gellan sol with selected cations. J. Food Sci. Technol. 2015, 52, 1233-1237. [CrossRef]

17. Vilela, J.A.P.; da Cunha, R.L. Emulsions stabilized by high acyl gellan and KCl. Food Res. Int. 2017, 91, 47-54. [CrossRef]

18. West, T.P.; Strohfus, B.; Santiago, M.F. A colorimetric assay for gellan elaborated by Sphingomonas paucimobilis ATCC 31461. World J. Microbiol. Biotechnol. 2000, 16, 529-531. [CrossRef]

19. Giavasis, I.; Harvey, L.M.; McNeil, B. Gellan gum. Crit. Rev. Biotechnol. 2000, 20, 177-211. [CrossRef]

20. Danalache, F.; Carvalho, C.; Alves, V.D.; Moldão-Martins, M.; Mata, P. Optimisation of gellan gum edible coating for ready-to-eat mango (Mangifera indica L.) bars. Int. J. Biol. Macromol. 2016, 84, 43-53. [CrossRef]

21. Tomadonia, B.; Moreira, M.R.; Pereda, M.; Ponce, A.G. Gellan-based coatings incorporated with natural antimicrobials in fresh-cut strawberries: Microbiological and sensory evaluation through refrigerated storage. LWT-Food Sci. Technol. 2018, 97, 384-389. [CrossRef]

22. Torresa, O.; Yamada, A.; Rigby, N.M.; Hanawa, T.; Kawano, Y.; Sarkar, A. Gellan gum: A new member in the dysphagia thickener family. Biotribiology 2019, 17, 8-18. [CrossRef]

23. Shinsho, A.; Brenner, T.; Descallar, F.B.; Tashiro, Y.; Ando, N.; Zhou, Y.; Ogawa, H.; Matsukawa, S. The thickening properties of native gellan gum are due to freeze drying-induced aggregation. Food Hydrocoll. 2020, 109, 105997. [CrossRef]

24. Linn, C.C.; Cassida, L.E. Gelrite as a gelling agent in media for the growth of thermophilic microorganisms. Appl. Environ. Microbiol. 1984, 47, 427-429. [CrossRef] [PubMed]

25. Rygaard, A.M.; Thøgersen, M.S.; Nielsen, K.F.; Gram, L.; Bentzon-Tilia, M. Effects of gelling agent and extracellular signaling molecules on the culturability of marine bacteria. Appl. Environ. Microbiol. 2017, 83, e00243-17. [CrossRef] [PubMed]

26. McGuffey, J.C.; Leon, D.; Dhanji, E.Z.; Mishler, D.M.; Barrick, J.E. Bacterial production of gellan gum as a do-it-yourself alternative to agar. J. Microbiol. Biol. Educ. 2018, 19, 1530. [CrossRef]

27. Crescenzi, V.; Dentini, M.; Segatori, M.; Tiblandi, C.; Callegaro, L.; Benedetti, L. Synthesis and preliminary characterisation of new esters of the bacterial polysaccharide gellan. Carbohydr. Res. 1992, 231, 73-81. [CrossRef]

28. Osmałek, T.; Froelich, A.; Tasarek, S. Application of gellan gum in pharmacy and medicine. Int. J. Pharm. 2014, 466, 328-340. [CrossRef]

29. Mahdi, M.H.; Conway, B.R.; Smith, A.M. Development of mucoadhesive sprayable gellan gum fluid gels. Int. J. Pharm. 2015, 488, 12-19. [CrossRef]

30. Wahba, M.I. Processed gellan gum beads as covalent immobilization carriers. Biocatal. Agric. Biotechnol. 2018, 14, 270-278. [CrossRef]

31. Zia, Z.M.; Tabasum, S.; Khan, M.F.; Akram, N.; Akhter, N.; Noreen, A.; Zuber, M. Recent trends on gellan gum blends with natural and synthetic polymers: A review. Int. J. Biol. Macromol. 2018, 109, 1068-1087. [CrossRef]

32. Kuhn, K.R.; e Silva, F.G.D.; Netto, F.M.; da Cunha, R.L. Production of whey protein isolate-Gellan microbeads for encapsulation and release of flaxseed bioactive compounds. J. Food Eng. 2019, 247, 104-114. [CrossRef]

33. Palumbo, F.S.; Federico, S.; Pitarresi, G.; Fiorica, C.; Giammona, G. Gellan gum-based delivery systems of therapeutic agents and cells. Carbohydr. Polym. 2020, 229, 115430. [CrossRef]

34. Monier, M.; Shafik, A.L.; El-Mekabaty, A. Designing and investigation of photo-active gellan gum for the efficient immobilization of catalase by entrapment. Int. J. Biol. Macromol. 2020, 161, 539-549. [CrossRef] [PubMed]

35. Sun, J.; Zhou, Z. A novel ocular delivery of brinzolamide based on gellan gum: In vitro and in vivo evaluation. Drug Des. Dev. Ther. 2018, 12, 383-389. [CrossRef]

36. Moxon, S.R.; Smith, A.M. Controlling the rheology of gellan gum hydrogels in cell culture conditions. Int. J. Biol. Macromol. 2016, 84, 79-86. [CrossRef] [PubMed] 
37. Sebri, N.J.M.; Amin, K.A.M. Gellan gum/ibuprofen hydrogel for dressing application: Mechanical properties, release activity and biocompatibility studies. Int. J. Appl. Chem. 2016, 12, 483-498.

38. Lago, M.E.L.; da Silva, L.P.; Henriques, C.; Carvalho, A.F.; Reis, R.L.; Marques, A.P. Generation of gellan gum-based adipose-like microtissues. Bioengineering 2018, 5, 52. [CrossRef]

39. Manda, M.G.; da Silva, L.P.; Cerqueira, M.T.; Pereira, D.R.; Oliveira, M.B.; Mano, J.F.; Marques, A.P.; Oliveira, J.M.; Correlo, V.M.; Reis, R.L. Gellan gum-hydroxyapatite composite spongy-like hydrogels for bone tissue engineering. J. Biomed. Mater. Res. Part A 2018, 106A, 479-490. [CrossRef] [PubMed]

40. Muthukumar, T.; Song, J.E.; Khang, G. Biological role of gellan gum in improving scaffold drug delivery, cell adhesion properties for tissue engineering applications. Molecules 2019, 24, 4514. [CrossRef]

41. Wang, X.; Xu, P.; Yuan, Y.; Liu, C.; Zhang, D.; Yang, Z.; Yang, C.; Ma, C. Modeling for gellan gum production by Sphingomonas paucimobilis ATCC 31461 in a simplified medium. Appl. Environ. Microbiol. 2006, 72, 3367-3374. [CrossRef]

42. Lim, S.-M.; Wu, J.R.; Lee, J.-W.; Kim, S.-K. Optimization of culture condition for gellan production by Pseudomonas elodea ATCC 31461. Korean J. Life Sci. 2003, 13, 705-711.

43. West, T.P.; Strohfus, B. Effect of complex nitrogen sources upon gellan production by Sphingomonas paucimobilis ATCC 31461. Microbios 1998, 94, 145-152.

44. Kanari, B.; Banik, R.R.; Upadhyay, S.N. Effect of environmental factors and carbohydrate on gellan gum production. Appl. Biochem. Biotechnol. 2002, 102-103, 129-139. [CrossRef]

45. West, T.P. Effect of temperature on bacterial gellan production. World J. Microbiol. Biotechnol. 2003, 19, 649-652. [CrossRef]

46. Zhu, G.; Sheng, L.; Tong, Q. A new strategy to enhance gellan production by two-stage culture in Sphingomonas paucimobilis. Carbohydr. Polym. 2013, 98, 829-834. [CrossRef] [PubMed]

47. West, T.P.; Fullenkamp, N.A. Effect of culture medium pH on bacterial gellan production. Microbios 2001, 105, 133-140.

48. Zhu, G.; Guo, N.; Yong, Y.; Xiong, Y.; Tong, Q. Effect of 2-deoxy-D-glucose on gellan gum biosynthesis by Sphingomonas paucimobilis. Bioprocess Biosyst. Eng. 2019, 42, 897-900. [CrossRef]

49. West, T.P.; Strohfus, B. Effect of yeast extract on gellan production by Sphingomonas paucimobilis ATCC 31461. Microbios 1999, 97, 85-93.

50. Banik, R.M.; Santhiagu, A. Improvement in production and quality of gellan gum by Sphingomonas paucimobilis under high dissolved oxygen tension levels. Biotechnol. Lett. 2006, 28, 1347-1350. [CrossRef]

51. Giaviasis, I.; Robertson, I.; McNeil, B.; Harvey, L.M. Simultaneous and rapid monitoring of biomass and biopolymer production by Sphingomonas paucimobilis using Fourier transform-near infrared spectroscopy. Biotechnol. Lett. 2003, 25, 975-979. [CrossRef] [PubMed]

52. Zhu, G.; Sheng, L.; Tong, Q. Enhanced gellan gum production by hydrogen peroxide $\left(\mathrm{H}_{2} \mathrm{O}_{2}\right)$ induced oxidative stresses in Sphingomonas paucimobilis. Bioprocess Biosyst. Eng. 2014, 37, 743-748. [CrossRef]

53. Arockiasamy, S.; Banik, R.M. Optimization of gellan gum production by Sphingomonas paucimobilis ATCC 31461 with nonionic surfactants using central composite design. J. Biosci. Bioeng. 2008, 105, 204-210. [CrossRef] [PubMed]

54. Harding, N.E.; Patel, Y.N.; Coleman, R.J. Organization of genes required for gellan polysaccharide biosynthesis in Sphingomonas elodea ATCC 31461. J. Ind. Microbiol. Biotechnol. 2004, 31, 70-82. [CrossRef] [PubMed]

55. Silva, E.; Marques, A.R.; Fialho, A.M.; Granja, A.T.; Sa'-Correia, I. Proteins encoded by Sphingomonas elodea ATCC 31461 rmlA and $u g p G$ genes, involved in gellan gum biosynthesis, exhibit both dTDP- and UDP-glucose pyrophosphorylase activities. Appl. Environ. Microbiol. 2005, 71, 4703-4712. [CrossRef]

56. Attallah, A.G.; Abd-El-Aal, S.K.; Ibrahim, S.A.; El-Sayd, M.A. Improvement the efficiency of Sphingomonas paucimobilis to produce gellan gum by genetically approach. Int. J. ChemTech Res. 2014, 6, 64-79.

57. Marques, A.R.; Ferreira, P.B.; Sa'-Correia, I.; Fialho, A.M. Characterization of the ugpG gene encoding a UDP-glucose pyrophosphorylase from the gellan gum producer Sphingomonas paucimobilis ATCC 31461. Mol. Gen. Genom. 2003, 268, 816-824. [CrossRef]

58. Aragáo, D.; Fialho, A.M.; Marques, A.R.; Mitchell, E.P.; Sa'-Correia, I.; Frazáo, C. The complex of Sphingomonas elodea ATCC 31461 glucose-1-phosphate uridylyltransferase with glucose-1-phosphate reveals a novel quaternary structure, unique among nucleoside diphosphate-sugar pyrophosphorylase members. J. Bacteriol. 2007, 189, 4520-4528. [CrossRef]

59. Granja, A.T.; Popescu, A.; Marques, A.R.; Sá-Correia, I.; Fialho, A.M. Biochemical characterization and phylogenetic analysis of UDP-glucose dehydrogenase from the gellan gum producer Sphingomonas elodea ATCC 31461. Appl. Microbiol. Biotechnol. 2007, 76, 1319-1327. [CrossRef]

60. Vartak, N.B.; Lin, C.C.; Cleary, J.M.; Fagan, M.J.; Saier, M.H., Jr. Glucose metabolism in 'Sphingomonas elodea': Pathway engineering via construction of a glucose-6-phosphate dehydrogenase insertion mutant. Microbiology 1995, 141, 2339-2350. [CrossRef]

61. West, T.P. Isolation of a mutant strain of Pseudomonas sp. ATCC 31461 exhibiting elevated polysaccharide production. J. Ind. Microbiol. Biotechnol. 2002, 29, 185-188. [CrossRef]

62. West, T.P. Improved polysaccharide production using strain improvement. In Microbial Processes and Products; Barredo, J.-L., Ed.; Humana Press Inc.: Totowa, NJ, USA, 2005; Chapter 17; pp. 301-312.

63. Li, A.; Hu, T.; Luo, H.; Alam, N.-U.; Xin, J.; Li, H.; Lin, Y.; Huang, J.; Meng, Y.; Meng, F.; et al. A carotenoid- and poly- $\beta$ hydroxybutyrate-free mutant strain of Sphingomonas elodea ATCC 31461 for the commercial production of gellan. mSphere 2019, 4, e00668-19. [CrossRef] 
64. Dlamini, A.M.; Peiris, P.S. Production of exopolysaccharide by Pseudomonas sp. ATCC 31461 (Pseudomonas elodea) using whey as fermentation substrate. Appl. Microbiol. Biotechnol. 1997, 47, 52-57. [CrossRef]

65. Fialho, A.M.; Martins, L.O.; Donval, M.-L.; Leitao, J.H.; Ridout, M.J.; Jay, A.J.; Morris, V.J.; Sá-Correia, I. Structures and properties of gellan polymers produced by Sphingomonas paucimobilis ATCC 31461 from lactose compared with those produced from glucose and from cheese whey. Appl. Environ. Microbiol. 1999, 65, 2485-2491. [CrossRef] [PubMed]

66. West, T.P.; Strohfus, B. Effect of carbon source on exopolysaccharide production by Sphingomonas paucimobilis ATCC 31461. Microbiol. Res. 1998, 153, 327-329. [CrossRef]

67. West, T.P.; Fullenkamp, N.A. Ability of casamino acids to support gellan production by Sphingomonas paucimobilis ATCC 31461. Microbios 2000, 102, 89-101.

68. Huang, J.; Zhu, S.; Li, C.; Zhang, C.; Ji, Y. Cost-effective optimization of gellan gum production by Sphingomonas paucimobilis using corn steep liquor. Prep. Biochem. Biotechnol. 2020, 50, 191-197. [CrossRef] [PubMed]

69. Vanderhoff, A.; Gibbons, W.R.; Bauer, N.; West, T.P. Development of a low-cost medium for producing gellan from Sphingomonas paucimobilis. J. Biotech Res. 2010, 2, 67-78.

70. Nampoothiri, K.M.; Singhania, R.R.; Sabarinath, C.; Pandey, A. Fermentative production of gellan using Sphingomonas paucimobilis. Process Biochem. 2003, 38, 1513-1519. [CrossRef]

71. Bajaj, I.B.; Saudagar, P.S.; Singhal, R.S.; Pandey, A. Statistical approach to optimization of fermentative production of gellan gum from Sphingomonas paucimobilis ATCC 31461. J. Biosci. Bioeng. 2006, 102, 150-156. [CrossRef]

72. Banik, R.R.; Santhiagu, A.; Upadhyay, S.N. Optimization of nutrients for gellan gum production by Sphingomonas paucimobilis ATCC-31461 in molasses based medium using response surface methodology. Bioresour. Technol. 2007, 98, 792-797. [CrossRef] [PubMed]

73. Jin, H.; Lee, N.-K.; Shin, M.-K.; Kim, S.-K.; Kaplan, D.L.; Lee, J.-W. Production of gellan gum by Sphingomonas paucimobilis NK2000 with soybean pomace. Biochem. Eng. J. 2003, 16, 357-360. [CrossRef]

74. Giavasis, I.; Petrotos, K. Biovalorization of olive mill waste water for the production of gellan gum from Sphingomonas paucimobilis. Br. Biotechnol. J. 2016, 11, 1-15. [CrossRef] 